\title{
KOMPLEXNÁ MONOGRAFIA MAPUJÚCA VÝVOJ FINANCIÍ NA ÚZEMÍ SLOVENSKA
}

\section{Martin Kocúrek ${ }^{*}$}

\section{Peter Baláži a kolektív: Historiografia financií na území Slovenska}

Praha: Wolters Kluwer, 2016. 272 strán. ISBN 978-80-7552-484-3.

Český a slovenský knižný trh obohatila vedecká monografia autorského kolektívu Petera Balážiho, ktorá komplexne a chronologicky mapuje históriu financií a finančnej vedy na území Slovenka od staroveku, až po súčasné pomery v jednotlivých štátoprávnych usporiadaniach, ktorého bolo súčast'ou. Z názvu publikácie sa na prvý pohl'ad môže zdat', že sa zaoberá iba problematikou Slovenska, avšak autori kladú dôraz na analýzu pomerov v dvadsiatom storočí, počas ktorého bolo územie Slovenska súčast’ou Československa (1918-1939 a 1945-1992), preto publikácia mapuje aj pomery v Čechách, na Morave a v Sliezsku v tomto období.

Je potrebné ocenit' snahu autorského kolektívu, ktorý v knihe pamätal aj na financov a národohospodárov, ktorí sa zaslúžili o rozvoj financií a finančnej vedy, predovšetkým profesor in memoriam Vladimír Háčik, ktorý pôsobil na Fakulte národohospodárskej Vysokej školy ekonomickej v Bratislave a vydal monografiu Finančná propedeutika: úvod do financií $(1969,1971)$, profesor Soblík s jeho monografiou Verejné finance Československa (1947), d’alej profesori in memoriam: Juraj Trnovský, Milan Majcher, Jozef Košnár, Ján Petrenka, ako aj Ing. Michal Bodorovčák, CSc.

Pridaná hodnota monografie spočíva vo využití primárnych, originálnych zdrojov, ktoré boli kriticky prehodnocované a syntetizované a zároveň obohatené o nové poznatky a sú výsledkom vedeckého výskumu autorov. $Z$ primárnych zdrojov je potrebné spomenút' predovšetkým dielo profesora Josefa Kaizla - Finanční věda, část I. a II., vydané v roku 1888 v Hustopeči.

Prvá kapitola uvedie čitatel’a do problematiky teoretických aspektov financií a oboznámi ho s poznatkami o ekonomickej a finančnej vede, charakteristike jednotlivých finančných pojmov a finančných kategórií, ekonomickej podstate financií, objektívnej a subjektívnej stránke financií, členenia finančného systému a perspektív smerovania finančnej vedy.

Druhá kapitola prináša detailné chronologické spracovanie histórie financií v jednotlivých štátoprávnych usporiadaniach. Autori najprv rozoberajú situáciu v starovekom Oriente, Grécku a Rímskej ríši, pričom je kriticky analyzovaná jej daňová sústava

* Martin Kocúrek (martin.kocurek@euba.sk), Ekonomická univerzita v Bratislave, Národohospodárska fakulta. 
a hospodárska situácia. Z pochopitel'ných historických dôvodov nie je možné venovat' detailnú pozornost' finančnej sústave Vel'kej Moravy, nakol'ko tá nebola rozvinutá, preto autori venujú podrobnejší pohl'ad až na dejiny Uhorska, kde pozitívne hodnotím predstavenie daňovej reformy čitatel'ovi, realizovanej v rokoch 1336-1346 Karolom I. Róbertom, ktorá zaviedla pravidelnú daň z výmeny mincí (tzv. kazenie), platenie naturálnych daní a položila základy t’ažby drahých kovov na Slovensku. Taktiež viedla k založeniu Mincovne Kremnica, ktorá dodnes zohráva dôležitú úlohu v európskom i svetovom mincovníctve. Autorom neunikli zmeny spojené s centralizáciou štátnych financií realizovaných viedenským dvorom začiatkom 16. storočia, kedy sa Uhorsko stalo súčast'ou habsburskej monarchie, pričom prínosom je skutočnost', že kolektív autorov správne zdôraznil špecifickost' uhorského daňového systému oproti rakúskemu. Na pozadí Baláži a kol. spomínajú aj politické udalosti, ktoré viedli k zmene z centralizmu k federálnemu usporiadaniu Rakúska-Uhorska v roku 1867 a ňou vyvolanú reformu verejnej správy, ktorá priniesla nové postupy v hospodárení štátu - bilanciu dôchodkov a spotrebných výdavkov, resp. číselný plán budúcej hospodárskej periódy ako predchodcu moderného štátneho rozpočtu.

Pozitívne hodnotím snahu autorov detailne sa venovat' názorovým prúdom na riadenie národného hospodárstva prvej Československej republiky, a to liberálnym myšlienkam Aloisa Rašína a Karla Engliša na jednej strane a keynesiánskym myšlienkam Josefa Macka a Jaroslava Nebesáŕa na strane druhej. Prínosom je analýza hospodárskej politiky realizovanej od polovice 20. rokov 20. storočia v duchu myšlienok Karla Engliša: ,... postarajte sa o vyrovnaný štátny rozpočet a ostatné vám bude pridané“. Autori identifikujú a hodnotia špecifické problémy československého hospodárstva spôsobené predovšetkým externými okolnost’ami sprevádzajúcimi vznik nového štátu, v dôsledku čoho nebolo možné plne presadit' myšlienky Aloisa Rašína spočívajúce v úsporných opatreniach vlády, zákazu deficitného rozpočtovania a zavádzaní nových daní, čo postupne viedlo k aplikácií Englišovej rozpočtovej koncepcie a koncepcie reformy daňového systému v roku 1927, ktorý je detailne analyzovaný. Autori sa opierajú aj o články F. Vencovského: Stání finance v historii Československa - obdobi 1918-1947 (1994) a K rozpočtové a daňové reformě před sedmdesáti roky (1997) publikovaného vo Finance a úvěr.

Následne je analyzovaná situácia počas druhej svetovej vojny, pričom pozornost' je venovaná problematike zostavovania a vývoja salda štátneho rozpočtu Československa (ČSR), neskôr Slovenskej republiky (1939-1945) a Protektorátu Čechy a Morava (1939-1945) počas vojnových rokov a vývoju v obnovenej ČSR po komunistický prevrat v roku 1948. Čitatel' sa má možnost' detailne oboznámit’ s problematikou menovej reformy v ČSR uskutočnenej v roku 1953, problémom ktoré jej predchádzali, jej priebehu a dôsledkom, pričom sa autori opierajú o primárne zdroje z dobovej tlače. Zdôraznená je snahu profesora Ota Šika a d’alších akademikov o reformné kroky, s cielom odstránenia centrálne riadeného systému ekonomiky a nastolením trhového mechanizmu. Obdobie tzv. normalizácie od prijatia ústavného zákona č. 143/1968 Zb. o československej federácii až po rozdelenie ČSFR je zamerané predovšetkým na analýzu štátneho rozpočtu a systému fiškálneho federalizmu, kde sa autori opierajú o platnú legislatívu v danom období, vlastnú výskumnú činnost’ a článok I. Kočárníka $-K$ vývoji fiskálního 
federalismu v ČSFR (1991), publikovaného vo Finance a úvěr. Záver druhej kapitoly tvorí podkapitola definujúca teoretické aspekty finančných inštitúcii a štátneho rozpočtu.

Baláži a kol. usporiadali monografiu do ucelených tematických kapitol, kde sa $\mathrm{v}$ tretej kapitole venujú štúdiu vývoja municipálnych financií a verejných rozpočtov. Najprv sú analyzované slobodné král'ovské mestá v Uhorsku od 13. storočia, odkedy sa územie Slovenska stalo jeho najrozvinutejšou čast’ou. Autori zdôrazňujú na tú dobu pokrokový fakt, že vedenie mesta bolo volené jeho obyvatel'stvom, pričom v okolitých krajinách zástupcov miest menoval panovník. Svoju pozornost' upriamili aj na tzv. slobodné banské mestá, vo väčšine ktorých prebiehala t’ažba drahých kovov a ktorých legislatívny systém bol na vysokej úrovni. Analyzovaný je rozpočet banského mesta Kremnica, kde sa autori opierajú o historické pramene a monografiu T. Lamoša Vznik a počiatky banského a mincového mesta Kremnica (1969). Postavenie miest dávajú do kontrastu s postavením obcí, ktorých postavenie v danom období bolo horšie, pričom uvádzajú konkrétne príklady. Osobitú pozornost' venujú aj územnosprávnym jednotkám - stoliciam, stavovským inštitúciám šlachty, pomocou ktorých panovník zabezpečoval administratívnu, daňovú a súdnu správu. Revolučné roky 1848-1849 vyvolali zmeny v územnosprávnom členení, prijatím tzv. župného zákona $\mathrm{v}$ rokoch 1870-1871. Autori opät' prinášajú analýzu rozpočtu mesta Kremnica, avšak po hospodárskom úpadku mesta v 18. a 19. storočí, spolu a analýzou rozpočtu obce Kluknava v rokoch 1711-1918.

Osobitným prínosom je analýza systému miestnych a regionálnych samospráv po vzniku ČSR, pričom Baláži a kolektív sa vo svojej analýze, okrem iného, opierajú o legislatívu platnú v danom období - Zákon č. 210/1920 Sb., o prozatímní úpravě správy politické na Slovensku, Zákon č. 211/1920 Sb., o obecních a obvodních notařich na Slovesnku, Zákon č. 233/1920 Sb. o prozatímni úpravě správy mèst s regulovaným magistrátem na Slovesnsku a Zákon č. 43/1922 Sb. o oddeleni státni finančné správy od obecné a municipální správy na Slovensku a v Podkarpatské Rusi - ako aj o primárne zdroje zo štátneho archívu. Upozorňujú na problematiku nejednotného územnosprávneho členenia v krajinách českých a na Slovensku, a to ako pozostatok dvoch paralelných systémov z rakúskej a uhorskej časti monarchie. Problematiku mal riešit’ tzv. župný zákon, avšak ten nebol schválený a pristúpilo sa k usporiadaniu na kraje, okresy a obce. Následne je čitatel' oboznámený so situáciou počas druhej svetovej vojny, pričom autori ponúkajú analýzu verejného rozpočtu obce Kluknava v tomto období.

Komunistický štátny prevrat v roku 1948 znamenal zásadné zmeny vo financiách samospráv, ktoré mali do roku 1990 podobu rozpočtov národných výborov, pričom došlo k zlúčeniu miestnej samosprávy a miestnych štátnych orgánov a z pôvodne zastupitel'ských orgánov sa stali orgány štátnej moci v príslušných krajoch, okresoch a obciach. Ďalšia čast' kapitoly analyzuje špecifiká sústavy rozpočtového hospodárenia národných výborov do roku 1990, pričom sa autori opierajú o legislatívu platnú v danom období a následne zmeny po roku 1990 až po súčasný stav. V závere kapitoly sú čitatel’ovi ponúknuté prípadové štúdie - miestny rozpočet obce Rabča a rozpočet mesta Kremnica.

Predmetom štvrtej, záverečnej kapitoly je historiografia finančnej správy na území Slovenska vrátane historiografie účtovníctva a národného účtovníctva, ktoré autori 
analyzujú od počiatku obdobia vlády Márie Terézie v roku 1740 v dôsledku zavedenia dôležitých prelomových reforiem. Najväčšiu pozornost' autori venujú obdobiam od roku 1848 a obdobiu prvej ČSR.

Kolektív autorov analyzuje predovšetkým reformy Márie Terézie v oblasti daní a štátnej správy, vyvolané vysokým deficitom štátnych financií, ako dôsledok prehratej vojny s Pruskom v roku 1740. V reformách pokračoval Jozef II, avšak obdobie vlády Leopolda II. (1790-1848) sa nieslo v duchu rušenia reforiem. Autori spomínajú založenie Ministerstva financií v roku 1848 a reformu priamych daní a zavedením štyroch druhov výnosových daní. Následne je detailne analyzovaná sústava finančnej správy po rok 1918. Baláži a kolektív charakterizujú ekonomické udalosti pri vzniku ČSR a hospodársku situáciu doma aj vo svete. Zdôrazňujú reformu finančnej správy, kedy bola oddelená od politickej a porovnávajú daňovú sústavu z roku 1921 a reformu priamych daní v ČSR v roku 1927 a inštitúcie finančnej správy a ich kompetencie do roku 1939. Následne je stručne analyzovaná situácia počas druhej svetovej vojny a obdobie komunizmu.

V rámci analýzy počtovníctva, účtovníctva a účtovnej evidencie sa autori venujú významným prelomovým obdobiam vo svete aj na Slovensku, osobitostiam vedenia účtovnej evidencie a jej vývoj až po súčasnost'. Autori prinášajú teoretické aspekty účtovníctva, definujú jeho funkcie a venujú sa jeho histórií od staroveku. Následne jeho vývoj ČSR až po súčasnost'. Charakterizovaná je harmonizácia účtovníctva a zavedenie medzinárodných štandardov US GAP a IFRS.

Historiografia národného účtovníctva skúma problematiku makroekonomických systémov štatistických informácií, ktoré využívajú jednak ekonomickú teóriu, ako aj hospodársku štatistiku. Autori definujú jeho funkcie, ako aj teoretické aspekty a aplikáciu v praxi, kriticky analyzujú systémy národných účtov a systémy bilancie národného hospodárstva, štandardy USA a súčasné štandardy.

Vedecká monografia Balážiho a kolektívu je z mnohých aspektov významná a jedinečná. V porovnaní s ostatnými publikáciami nie je zameraná iba výlučne na dejiny hospodárstva, ale poskytuje širokej aj odbornej verejnosti komplexne spracovaný záber. Prináša teoretické aspekty finnancií na oboznámenie sa s problematikou, následne chronologické spracovanie histórie financií, teoretické aspekty a históriu municipálnych financií a verejných rozpočtov a historiografiu finančnej správy. Tieto sú obohatené o prípadové štúdie a záujemcom podávané spolu s historickými súvislost’ami. 